\title{
IMPROVING THE CAPABILITY OF SCHOOL SCIENCE LABORATORY MANAGERS THROUGH SCHOOL SUPERVISION ASSISTANCE IN CLUSTER I OF BAGUALA DISTRICT, AMBON CITY
}

\author{
Jotty Sartje Haumahu \\ Dinas Pendidikan Kota Ambon, Maluku \\ e-mail: jotthyhau@gmail.com
}

\begin{abstract}
This study aims to improve the ability of school science laboratory managers through mentoring school supervisors in cluster I of Baguala district in Ambon City. This research begins with the researchers' findings in the pre-cycle stage where the management of the Natural Sciences Laboratory in 4 of these schools has not been managed properly in accordance with the National Library Standards (SNP: Standar Nasional Perpustakaan). This research is a School Action Research (PTS: Penelitian Tindakan Kelas) conducted in 2 mentoring cycles that contain stages of planning, implementation and reflection (evaluation) and accompanied by a standard of success (minimum of $75 \%$ ). The results of mentoring in cycle 1 have not shown satisfactory results due to various deficiencies in the mentoring instruments in Junior High School 7 Ambon, Junior High School 13 Ambon, Junior High School 20 Ambon, and Junior High School 21 Ambon. Under these conditions further assistance was made in cycle 2 where the result was that all the mentoring instruments had been repaired and completed by the manager of the school's Science Laboratory. The results of this study indicate that mentoring school supervisors can improve the ability of the Science Laboratory managers in these four schools.
\end{abstract}

Keywords: Science Laboratory, School Supervision Assistance

\section{Introduction}

The Science Laboratory serves as a place for learning activities that require special equipment that is not easily presented in the classroom. In the context of education in schools, the laboratory serves as a place for the learning process with practical methods that can provide learning experiences for students to interact with tools and materials, as well as observing various symptoms directly. Therefore, school principals, managers, science teachers, and other related school elements must be able to manage and utilize science laboratories effectively and efficiently, so as to improve the quality of science learning processes and outcomes for students (Sutrisno, 2007: 46).

Understanding the laboratory, in the National Indonesian Dictionary mentioned that the laboratory is a place or other equipped with equipment for conducting experiments and so on (Tim Penyusun Kamus, 1994).The laboratory is a place where experiments and investigations are carried out. The intended place can be a closed room, room or open space, for example a garden. In a limited way, the laboratory can be viewed as a closed room where an experiment and an investigation are conducted (Depdikbud, 1997). Generally the room in this case is where practical learning activities take place that require special equipment that is not easily presented in the classroom.

The effectiveness of science laboratory management is influenced by the availability of laboratory facilities and the competence of science laboratory management (Salirawati, 2012: 4). Science laboratory management includes coordinating practicum activities with the teacher, arranging laboratory schedule, monitoring implementation, laboratory

Received September $12^{\text {nd }} 2019$, Revision January $21^{\text {st }} 2020$, Accepted for publication February $18^{\text {th }} 2020$.

Copyright (C) 2020 Published by FKIP - Unpatti, ISSN 2721-3110 
activities, evaluating laboratory activities, managing school laboratory activities, compiling laboratory activity reports, and coordinating practicum activities.

Basically the responsibility of managing a laboratory is a shared responsibility of both the manager and the user. This is in accordance with the Minister of National Education Regulation Number 24 Year 2007 dated June 28, 2007 concerning the Standards for School,Public Education Facilities and Infrastructure, including requiring a SMP at least must have a science laboratory room. In the Republic of Indonesia Government Regulation Number 19 of 2005 concerning National Education Standards and Presidential Decree Number 32 of 2013 concerning Amendment to President Decree Number 19 of 2005, requires that each school must have a science laboratory management room. Furthermore it is required that the education staff in each school consist of at least the principal, administrative staff, management staff of the science laboratory, and school janitors. This regulation requires that every school should have a science laboratory management staff.

Thus, the existence of a science laboratory becomes a basic need and is very important to support the success of science learning in junior high schools. This is also in accordance with the way of learning science in junior high school as written in the 2013 curriculum, which requires students to carry out scientific processes which include observing, questioning, linking, conducting experiments, analyzing data, and concluding. The important point is the Science Laboratory is one of the school facilities where teachers and students conduct science learning activities through practical work to develop a scientific approach in accordance with the 2013 Curriculum.

The observation of researchers in several schools running the 2013 curriculum (SMP Negeri 7, 13, 20, and 21 Ambon) incorporated in cluster I in the Baguala District of Ambon City conducted through the academic supervision program found that the science laboratory had not met the standards set by the SNP. There are science laboratories that do not yet have an organizational structure, floor plan, rules of conduct, work programs, usage schedules, inventory lists, maintenance programs and equipment material requests, substances procurement proposals, goods improvement proposals, KIT usage reports, trial reports and student book inventory documents of the grade VII, VIII, and IX.

This shows that the management of the school's science laboratory has not been carried out effectively so that the intended benefits and objectives are not achieved. To overcome this, assistance is needed to remedy shortcomings and improve the ability to manage science laboratories in these schools. Mentoring activities must be carried out by competent people and school supervisors (specifically science supervisors) can be a guide for the management of the science laboratory to correct the deficiencies in the management of the science laboratory in their school.

Based on the background explanation above, the researchers determined a study entitled "Improving the Ability of School Science Laboratory Managers through School Supervision Assistance in Cluster I of Baguala District, Ambon City".

The Objective of the study are: Objective and Significance of the Study are

a. Improving the ability of science laboratory managers to manage school science laboratories through mentoring activities for school supervisors.

b. Describe the process of implementing school supervisors' mentoring to improve the ability of the school's science laboratory management in cluster I of Baguala subdistrict, Ambon City.

Assistance is defined as a form of interpersonal relations between someone who is seen as more experienced or more professional and someone who is positioned is still inexperienced or less professional. Assistance can also be interpreted as a process of sharing skills and experiences directly or indirectly to encourage the process of growing and developing increasing potential. Assistance can mean coaching, teaching, directing in groups that are more connotative to mastering, controlling and controlling (Suhardi, 2012: 86).The word accompaniment (assistance) is more meaningful in togetherness, equality,

Received September $12^{\text {nd }} 2019$, Revision January $21^{\text {st }} 2020$, Accepted for publication February $18^{\text {th }} 2020$.

Copyright (C) 2020 Published by FKIP - Unpatti, ISSN 2721-3110 
standing side by side and because of the equal standing between the two (the one who accompany and the one who being accompanied).The Definition of Assistance.

In general, assistance is provided to improve the ability to manage of school scientific laboratories which lead to an increase in the quality of education. In the context of this research, specifically the assistance was made as: (1) Solution for the school scientific laboratories manager to increase the sincerity, enthusiasm, and creativity of the school scientific laboratories manager to carry out their duties; (2) Strategies for school supervisors to be able to do coaching that is human in nature that can foster acceptance of the activities carried out; (3) overcoming various challenges in implementing the activities of managing school scientific laboratories (4) forming new ideas for the growth of various effective and friendly coaching patterns. Assistance is carried out in partnership, humane, varied but still focused on the goals set.

On the other hand Ethics assistance have to consider the following matters:

a) Explain in a fun way the purpose of conductingassistance (routine)

b) Be friendly and accept / accommodate all suggestions

c) Give priority to strength and ask questions about how to overcome or solutions that can be done by the manager of the school science laboratory.

d) Try not to feel that you are in a higher / better position than the person you are assisted, your position as a colleague or friend (team teaching).

e) Show your intention to help, and not to dictate or judge someone

f) Be polite and friendly with the manager of the laboratory who will be assisted to feel safe during the mentoring process.

g) Build the confidence of the manager who is being assisted

h) Build a sense of responsibility for what the manager did

i) Give the laboratory teacher confidence to reflect and evaluate themselves to improve the quality of laboratory management.

j) Give motivation and trust to the manager to make continuous improvements in the context of professional development

k) Prepare your time and yourself to consult with the manager which being assisted.

1) Get used to rewarding every innovation or ideas that the manager hadwhich beingassisted.

m) Make an agreement for the next meeting or accompaniment, adjusting to the manager's needs.

Assistance can be done in a variety of activities ranging from individuals, small groups and large groups. Each approach has advantages and disadvantages. The larger the group will accelerate the completion of coaching and mentoring but increasingly reduce its focus. On the other hand, individual or small group guidance can focus on coaching activities and objectives, but requires more time.

The Guidance Handbook (DBE, 2009: 6) explains that the entire assisiting process, especially when giving reflections, should consider the following:

a) Focus on facts / behavior and not on personal sentiment

b) Focused on one aspect

c) Leads to one aspect that can be changed.

d) Refers to the effect and not the cause of a problem

e) Clear ideas have to be conveyed

f) Give feedback on time

g) Praise in public, criticize in private / not in public.

h) Check whether feedback is understandable

i) Separating negative and positive feedback

j) Resolving feedback which has been adjusted with the person's personality.

k) Explain instead of judge.

l) Constructive

Received September $12^{\text {nd }} 2019$, Revision January $21^{\text {st }} 2020$, Accepted for publication February $18^{\text {th }} 2020$.

Copyright (C) 2020 Published by FKIP - Unpatti, ISSN 2721-3110 
Assistance activities must be carried out in stages to be more systematic and obtain maximum results. The steps in assistance are as follows:

\section{Planning activities (before assistance)}

The steps at the school where the study conducted is as follows,

a. Observation of videos of school science laboratory managers and write school science laboratory management models and discussed as a topic to find problems.

1) Developing a program for the development of a school science laboratory, namely managers compiling work programs, building and space data, floor plans, rules of organization, organizational structure, usage schedules, equipment maintenance programs, inventory lists of goods and substances, lists of proposed goods and substances, lists of income / expenses goods, list of proposals and improvements to goods, tool cards and goods cards, a list of trials using the KIT IPA and their reports, a list of trials that use materials from the environment and their reports, andstudents handbooks from class VII, VIII, and IX.

2) Assistance tasks (implementation)

a) Facilitating laboratory managers to obtain a proper understanding of teaching materials based on the curriculum.

b) Facilitating laboratory managers to obtain a proper understanding of laboratory management and services.

c) The implementation of assisting reflected and improved the management of the science laboratory..

d) Prepare reports no later than one week after the assistance has been completed.

3) Monitoring Process ( afterassistance)

a) Monitor the progress of the implementation assistance program

b) Know the level of success of the assistance program

c) Identify whichlesson learned (constraints, solutions, andgood practices)

There are several aspects that are seen in monitoring and evaluation, i.e:

a) Conformity between design and implementation of assistance activities in terms of implementation time, place of implementer, executor, assistant, target, scope of material, mechanism, and output, achievement of objectives.

b) Constraints / problems encountered and resolutions that have been implemented.

c) Things that support the assistance process

4) Activities carried out by an assistant (supervisor).

a. Giving motivations and encouragement.

b. Discussing the result which related to the strengths and weaknesses in managing the science laboratory.

c. Providing constructive criticism begins with several examples of new and good work as a result of management.

d. Discussion (findings in the management of the science laboratory, assistance to teachers and students).

Management is a process of utilizing resources effectively and efficiently to achieve an expected target optimally by taking into account the sustainability of the resource function. Functions in management include planning, organizing, coordinating, communicating, directing, implementing and supervising. While Ngalim Purwanto (2009: 14) added the management function / management to the evaluation activities. In laboratory management includes several aspects, namely as follows: (1) Planning, (2) Implementation, (3) evaluation. In addition, laboratory management is related to laboratory managers and facilities (buildings, laboratory equipment, biological experiments, chemical compounds).

The school's science laboratory as a source of learning has a parallel position with other learning resources such as libraries, skills / arts spaces, and factory workshops.

Received September $12^{\text {nd }} 2019$, Revision January $21^{\text {st }} 2020$, Accepted for publication February $18^{\text {th }} 2020$.

Copyright (C) 2020 Published by FKIP - Unpatti, ISSN 2721-3110 
Based on IFLA / UNESCO Guidelines, school science laboratories should be managed within a clearly structured policy framework. School science laboratory management policies are prepared by considering various school policies and needs that are comprehensive, and reflect the ethos, goals and objectives as well as the ethic of the school.

Assistance relationships occur in the realm of partnerships to exchange experiences in certain contexts. Mentoring can be done by a senior teacher, to the school or the school supervisor In this study, the mentoring process is carried out by the school supervisor to improve and enhance the ability of the school's science laboratory manager.

Assistance in the form of interpersonal relationships between a person who is deemed to have competence and someone who still needs to be improved, especially the competence in managing the school's science laboratory. The practice of facilitating school science laboratories is carried out, are as follows:

a. Provides a comfortable place to study

b. Providing practical material according to the needs of learning materials

c. Providing good service

d. Develop a schedule for using the Natural Sciences laboratory

e. Work with the teacher to make student books for all grade levels

f. Provide administration required by the science laboratory

Through the assistance process, it is expected to be able to achieve the following things:

a. Provide motivation to school science laboratory managers in implementing good, meaningful and quality management.

b. Give examples of professional guidance to supervisors, principals and other supervisors

c. Give better material and training to the school science laboratory manager in carrying out their duties.

d. Giving direct experience to the school science laboratory manager in management.

e. Help laboratory managers to understand, plan, and implement better management.

f. Improving the quality / professional management of school science laboratories.

In general, assistance is carried out to improve the ability to manage the school's science laboratory which results in an increase in the quality of education. In detail, the assistance is made as: (1) Solution for the school science laboratory manager to increase the sincerity, enthusiasm, and creativity of the school science laboratory manager to carry out their duties; (2) Strategies for school supervisors to be able to do coaching that is human in nature that can foster acceptance of the activities carried out; (3) overcoming various challenges in implementing the activities of managing the school's science laboratory (4) forming new ideas for the growth of various effective and friendly coaching patterns. Assistance is carried out in partnership, humane, and varied but still focuses on the goals set.

\section{Methodology}

This research is an action research that aims to improve the ability of science laboratory managers in managing the science laboratories in their respective schools. The action that will be taken is the assisting action using 2013 curriculum instruments. The four schools are the 2013 curriculum target schools. The research was conducted in SMP Negeri 7 Ambon, SMP Negeri 13 Ambon, SMP Negeri 20 Ambon and SMP Negeri 21 Ambon which is located in the Baguala atstrict, Ambon City. This research was conducted jointly between researchers as school supervisors with research subjects namely teachers who were given adattional tasks as administrators of the school's science laboratory. Starting from the formulation of the problem to the conclusion of the study.

Received September $12^{\text {nd }} 2019$, Revision January $21^{\text {st }} 2020$, Accepted for publication February $18^{\text {th }} 2020$.

Copyright (C) 2020 Published by FKIP - Unpatti, ISSN 2721-3110 
The research is planned in 2 cycles with the provisions that if the first cycle does not provide atrect improvement. Each cycle through 3 stages starts from planning, implementation, followed by reflection on the results of assistance (evaluation of followup). This continues to be repeated with action planning in the second cycle and so on.

Administration of Science Laboratory Managers in Managing the Science Laboratories of Each School

\begin{tabular}{|c|l|c|c|c|c|}
\hline \multirow{2}{*}{ No } & \multicolumn{1}{|c|}{ Laboratory Management } & $\begin{array}{c}\text { SMPN } \\
7\end{array}$ & $\begin{array}{c}\text { SMPN 13 } \\
\text { Ambon }\end{array}$ & $\begin{array}{c}\text { SMPN 20 } \\
\text { Ambon }\end{array}$ & $\begin{array}{c}\text { SMPN 21 } \\
\text { Ambon }\end{array}$ \\
\hline 1. & $\begin{array}{l}\text { Building data and Science Lab } \\
\text { room }\end{array}$ & & & & \\
\hline 2. & Plan of the science laboratory & & & & \\
\hline 3. & Rules of science laboratory & & & & \\
\hline 4. & $\begin{array}{l}\text { Science Lab organizational } \\
\text { structure }\end{array}$ & & & & \\
\hline 5. & Science Lab work program & & & & \\
\hline 6. & Science Lab usage schedule & & & & \\
\hline 7. & $\begin{array}{l}\text { Science Lab Planned Tool } \\
\text { Maintenance Program }\end{array}$ & & & & \\
\hline 8. & $\begin{array}{l}\text { Unplanned tool maintenance } \\
\text { program for a Science Lab }\end{array}$ & & & & \\
\hline 9. & Science Lab inventory list & & & & \\
\hline 10. & $\begin{array}{l}\text { List of inventory of substances / } \\
\text { chemicals }\end{array}$ & & & & \\
\hline 11. & List of receipt / release of goods & & & & \\
\hline 12. & $\begin{array}{l}\text { List of proposed substances / } \\
\text { chemicals }\end{array}$ & & & & \\
\hline 13. & $\begin{array}{l}\text { List of proposals and } \\
\text { improvements to goods }\end{array}$ & & & & \\
\hline 14. & The science laboratory tool card & & & & \\
\hline 15. & Science laboratory goods card & & & & \\
\hline 16. & $\begin{array}{l}\text { List of experiments using science } \\
\text { KIT }\end{array}$ & & & & \\
\hline 17. & $\begin{array}{l}\text { List of experiments using material } \\
\text { from the school environment }\end{array}$ & & & & \\
\hline 18. & Report on the use of science KIT & & & & \\
\hline 19. & $\begin{array}{l}\text { Report on the use of experimental } \\
\text { equipment from the environment }\end{array}$ & & & & \\
\hline 20. & Handbook grade VII & & & \\
\hline 21. & Handbook gradeVIII & & & \\
\hline 22. & Handbook gradeIX & & & \\
\hline & & & & \\
\hline
\end{tabular}

The research begins with an interview with the teacher who is the manager of the Science laboratory to make an agreement. Interviews were conducted before conducting research. The interview focused on how to manage the school's science laboratory. The next steps are carried out as follows:

\section{Cycle I}

a. Planning

Received September $12^{\text {nd }} 2019$, Revision January $21^{\text {st }} 2020$, Accepted for publication February $18^{\text {th }} 2020$.

Copyright (C) 2020 Published by FKIP - Unpatti, ISSN 2721-3110 
Some of the activities carried out during the planning stage include gathering and cooratnating with the managers of the Science laboratory and their staff from each school to determine a mutual agreement in arranging a schedule of mentoring activities.

b. Implementation

At the implementation stage, accoratng to the schedule that was agreed upon in advance, a mentoring process was initiated which began with the provision of material about the ideal management of the school's science laboratory and then each manager and his staff filled out worksheets that referred to the material delivery. The completion of the worksheet aims to arrange the administration of the development of science laboratories in each school. The results of the worksheet filling were then presented by each manager of the school's science laboratory in front of the assistant (school supervisor) accompanied by a question and answer interaction to find out the ability to understand how to manage the school's science laboratory.

The next process is filling instruments that contain components insulating: (1) Builating data and science laboratory room, (2) Science laboratory layout, (3) Science laboratory order, (4) Science laboratory organizational structure, (5) Work program science laboratories, (6) Schedule for use of natural science laboratories, (7) planned and unplanned equipment maintenance programs, (8) List of science and chemical laboratory inventory, (9) List of receipt / release of goods, (10) List of proposals for substance use / chemicals, (11) List of goods improvement proposals, (12) Science laboratory equipment and card items, (13) List of experiments using science KIT, (14) List of experiments using materials from the environment, (15) Report on use of science KIT , (16) Report on the use of experimental equipment from the environment, and (17) handbooks for grade VII, VIII, and IX students.

The purpose of filling this instrument is to determine the ability of the science laboratory management in each school. The results of the instrument filling in the form of several benchmark criteria will inatcate the real conattion of the management of the science laboratory in each school.

c. Reflection

After interpreting the results of the instrument filling, the next step is reflection. Reflection contains observations and understanatng of researchers through the filling of instruments to find out the real conattions of the science laboratory in each school. If the reflection results are good then the next cycle does not need to be held, but on the contrary, if the results are felt to be lacking then it needs to be continued with the next cycle, the second cycle. This relates to the success inatcators in which this study uses the K13 implementation assistance standards for the management of the school's science laboratory.

Indicators of success for laboratory management are $75 \%$ of science laboratory administration available in schools, with LKS at each level as much as $75 \%$ of science subject material (class VII 33 handbooks, class VIII 25 handbooks, class IX 18 handbooks).

If the administration and handbook value is below 75 , the laboratory manager does not meet the established success standards. Means, the actions taken are considered unsuccessful. Therefore, further action is needed to be carried out in cycle 2 .

2. Cycle II

a. Planning

Received September $12^{\text {nd }} 2019$, Revision January $21^{\text {st }} 2020$, Accepted for publication February $18^{\text {th }} 2020$.

Copyright (C) 2020 Published by FKIP - Unpatti, ISSN 2721-3110 
The activities carried out in the second cycle are basically the same as the first cycle. After seeing the results of the reflection in the first cycle, the second cycle was made planning to cooratnate with the management of the Natural Sciences laboratory as a research subject to conduct further assistance for each manager of the Natural Sciences laboratory in each school .

b. Iplementation

The implementation phase begins with the submission of the researchers' evaluation related to the results of filling the instrument accoratng to the criteria in cycle I. The process of continued mentoring by the researcher is carried out by proviatng a re-explanation of the criteria that have not been met by the school's science laboratory.

c. Reflection

After exposure to the results the next step is reflection. From the results of reflection it will be used to determine the next step. If the reflection results are good then the next cycle does not need to be held.

The location of the School action research (PTS) was carried out at:

1. SMP Negeri 7 Ambon

2. SMP Negeri 13 Ambon

3. SMP Negeri 20 Ambon

4. SMP Negeri 21 Ambon

In this study, the sample was teachers as managers of the science laboratory, totaling 4 teachers. As for the teacher who became the manager of the science laboratory as the subject in this study are:

Table 3.1

School Science Laboratory Manager

\begin{tabular}{|l|l|l|l|}
\hline No & \multicolumn{1}{|c|}{$\begin{array}{c}\text { Manager } \\
\text { School laboratory }\end{array}$} & \multicolumn{1}{|c|}{ NIP } & \multicolumn{1}{c|}{ School name } \\
\hline 1. & Louisa. Namumury, S.Pd & 198303102008042004 & SMP Negeri 7 Ambon \\
\hline 2. & MareykeWattimena & 196001271987032004 & SMP Negeri 13 Ambon \\
\hline 3. & Yohana Tahapary, S.Pd & 19670481992032007 & SMP Negeri 20 Ambon \\
\hline 4. & VonitaRumecky, S.Pd & 197203211994122005 & SMP Negeri 21 Ambon \\
\hline
\end{tabular}

The factors examined in this study were K13 implementation companion instruments for the management of a science laboratory consisting of:

1. Bulleting data and laboratory space for science

2. Science laboratory floor plan

3. Rules of science laboratory

4. The organizational structure of the science laboratory

5. Natural Sciences laboratory work program

6. Schedule for use of the science laboratory

7. Planned and unplanned tool maintenance programs

8. List of Science laboratory inventory and chemicals substances

9. List of receipt and goodsatsposal

10. List of chemical procurement proposals

11. List of goods improvement proposals

12. Tool cards and laboratory goods cards

13. List of experiments using scientific KIT

14. List of experiments using materials from the environment

15. Report on the use of scientific KIT

16. Report on the use of experimental equipment from the environment 
17. Grade VII, VIII, and IX student books

The next step after all data has been collected is the data processing stage. The collected data is then processed logically and systematically accoratng to the established research design. The stages of data processing are as follows:

a. Data reduction is a simplification process carried out through the selection, focusing and abstracting of raw data into meaningful information

b. Data exposure is a simple process of atsplaying data in narrative form, table format, matrix, graphics and so on

c. Conclusion is the process of taking the essence of the data presentation that has been organized in the form of a brief statement but contains a broad understanatng.

\section{Results}

\section{a. Assistance Cycle I}

In summary, the results of the assessment of assistance instruments will be seen in the table below :

Table 1. Summary of Mentoring Assessment Results School Science of Laboratory Manager in Cycle I

\begin{tabular}{|l|l|c|}
\hline Variable Presentation & School Name & Administration Situation \\
\hline \multirow{3}{*}{$\begin{array}{l}\text { Administrasi of Science } \\
\text { Laboratory }\end{array}$} & SMP N 7 Ambon & 36,8 \\
\cline { 2 - 3 } & SMP N 13 Ambon & 15,8 \\
\cline { 2 - 3 } & SMP N 20 Ambon & 21,1 \\
\cline { 2 - 3 } & SMP N 21 Ambon & 42,1 \\
\hline
\end{tabular}

The results obtained show that the ability of managers to manage school of science laboratories in cycle 1 has not met to the target in accordance with established indicators of success, namely $75 \%$ fulfillment of laboratory administration and the number of class VII handbooks (7 out of 33 expected), class VIII handbooks (6 handbooks out of 25 (25 expected)) and all handbooks (0 handbooks out of 18 (expected 18)). After reflection on the results obtained, it was decided to improve in terms of mentoring activities, especially focusing on the criteria that had not yet reached the established indicators of success.

\section{b. Assisitance Cycle2}

The results of the assistance in cycle 2 can be seen in the table below:

Table 2. Summary of Mentoring Assessment Results School Science of Laboratory Manager in Cycle 2

\begin{tabular}{|l|l|c|}
\hline Variable Presentation & School Name & Administration Situation \\
\hline \multirow{3}{*}{$\begin{array}{l}\text { Administrasi of Science } \\
\text { Laboratory }\end{array}$} & SMP N 7 Ambon & 100 \\
\cline { 2 - 3 } & SMP N 13 Ambon & 84 \\
\cline { 2 - 3 } & SMP N 20 Ambon & 78 \\
\cline { 2 - 3 } & SMP N 21 Ambon & 100 \\
\hline
\end{tabular}

The results obtained indicate that the ability of managers to manage school science laboratories in cycle 2 meets the target in accordance with established success 
indicators, namely $75 \%$ fulfillment of laboratory administration and the number of handbooks expected in laboratory management.

\section{Discussions}

Based on the results of the research as described in the previous section, it can be seen that in the mentoring process to improve and develop the management capabilities of a science laboratory it cannot be done in one mentoring or only until cycle 1 . This is because there are several items in the mentoring instrument that have not yet reached the point minimal success or in other words some still experience failure of assistance. School science labs that have failed due to the presentation mentoring ratings below $75 \%$ for each instrument accompaniment for SMP Negeri 7 Ambon, SMPN 13 Ambon, Ambon Negeri20 SMP and SMP 21 Ambon. Likewise, the handbooks in each school have not fulfilled the expected requirements.

This failure is then followed up by conducting further assistance, namely to cycle 2. Cycle 2 is directly directed to complete the administration of science laboratories that are still lacking, and to complete the worksheets of each class level. The result is that all schools can improve and develop school science laboratories, although not all schools have the maximum presentation.

The success of this action is due to a thorough understanding of the management of the school's science laboratory. With a good understanding, the process of managing a science laboratory can be carried out well. Optimizing the understanding of science laboratory managers towards the management of science laboratories through intensive coaching in the form of mentoring actions refers to the consultative cooperative method in which it is hoped that the managers of the science laboratories can discuss, cooperate and actively consult. This activity helps them understand the management of science laboratories in accordance with the National Standards of science laboratories as set out in Law No. 26 of 2008.

Related to coaching through mentoring, this research is also in line with what was delivered by Silberman (2004: 23) that the action of mentoring is able to improve mutual competence. In this research, there was an increase in the competencies of school science laboratory managers to manage their school science laboratories.

\section{Conclusion}

Based on the discussion in the previous chapter, it can be concluded that:

a. Pre-cycle research through initial observations about the management of the Natural Sciences laboratory was found that the management of the Natural Sciences laboratory was still not maximal or effective because the management of the Natural Sciences laboratory was still using the old way so that there had not been any changes in the management of the Natural Sciences laboratory. The results of the management of the Natural Science Laboratory in SMP Negeri 7 Ambon, SMP Negeri 13 Ambon, SMP Negeri 20 Ambon, and SMP Negeri 21 Ambon have not been maximized because they are still below the minimum assessment standard. For this reason, further assistance will be continued for the purpose of improvement

b. The results showed that the mentoring activities by school supervisors could improve the ability of the school's science laboratory management.

Received September $12^{\text {nd }} 2019$, Revision January $21^{\text {st }} 2020$, Accepted for publication February $18^{\text {th }} 2020$. 


\section{References}

Anna P, 2007. Management of Sciences Laboratory. Paper. Delivered to the Technical Assistance of Management of Natural Sciences Laboratory in the Science Program of Natural Sciences FMIPA UNDIKSA.

Government Regulations. 2005. Government Regulation No. 19/2005 concerningNational Education Standards. Jakarta

Government Regulations 2016. Government Regulation NumberGovernment Regulation Number 21 of 2016 concerning Basic and Secondary Education Content Standards. Jakarta

Kemdikbud. 2013. Teacher Training Materials Implementation of the 2013 Curriculum. Jakarta. Ministry of Education and Culture.

Laws of the republic Indonesia. 2003. Law Number 20 of 2003 concerning the National Education System. Jakarta

Ministry of Education and Culture. 2013. Guidelines for Assisting Curriculum Implementation. 2013. Jakarta.

National Agency for Stadaris. 2009. Indonesian National Standards (SNI 7329:2009). Jakarta

Suhardi. 2012. Skill Guide for School Supervisors Managing School Based Management. Department of Education and Sports. Kupang

Silberman. 2004. Active Learning. NusamediaandNuansa. Bandung

https://yusufaffandi11.wordpress.com/2014/03/17/pengelolaan-laboratoriumsekolah/Accessed October 10, 2016

http://bowobiologi.blogspot.co.id/2008/10/optimalisasi-pengelolaanlaboratorium.htmlAccessed October 10, 2016

Received September $12^{\text {nd }} 2019$, Revision January $21^{\text {st }} 2020$, Accepted for publication February $18^{\text {th }} 2020$. 